\title{
THE CONCEPT OF ACCOUNTABILITY BASED ON THE VALUE OF ISLAMIC JUSTICE
}

\author{
Salle Ilham Z. ${ }^{1,2 \star}$, Triyuwono Iwan ${ }^{2}$, Ludigdo Unti ${ }^{2}$, Rosidi ${ }^{2}$ \\ ${ }^{1}$ STIE Indonesia, Indonesia \\ ${ }^{2}$ Doctoral Degree Program in Accounting, University of Brawijaya, Indonesia \\ *E-mail: ilhamsalle@yahoo.com
}

\begin{abstract}
This study aims to find Islamic values that can be used to develop the concept of accountability. This research has employed bayani, burhani, and irfani as methods. This research was conducted at the Institute of Zakat in Indigenous Region of Ammatoa. The research found that the concept of accountability is based on the values of justice. This comprises three elements: justice divert mandate (amanah), justice in the conduct of amanah, and accounting for the value of justice in amanah.
\end{abstract}

\section{KEY WORDS}

Accountability, justice, bayani, burhani, irfani.

Accountability serves to enhance the performance benchmarks in providing public services, increase managerial accountability process, and as an element management control in organizations (Sadjarto 2000; Fikri et al. 2010; Fikri and Isnaini 2013; and Salle 2015). The demand for transparency in the management process requires an accountability pattern that is built through accounting system in order to provide opportunities to improve the provision of information that is accurateand reliable (Salle 2015). It has become a necessity in the management process, because each organization has to build relationship with the organization's internal and external parties.

In the last decade, attention and effort to uncover the link between accounting and accountability with religion have undergone many improvements, such as shown in the study by Lehman (2004), Triyuwono (2004), Quattrone (2004), Kholmi (2010), and Randa et al. (2011). The study focused on the relationship between accounting and accountability to religion on moral and ethical order. These studies were motivated by their concern over the tendency of increasing distance between accounting science and religion and theism. Modernization is characterized by a disregard for theism. For Lehman (2004), this is considered as the main cause of estrangement link between moral and ethics derived from religious teachings with accounting practices as a key explanatory accountability. Research on accountability in the non-business religious organizations have been carried out by Randa et al. (2011); Simanjuntak and Januarsi (2011); and Hadi and Yana (2011).Randa et al. (2011), for example, examineda religious Non Governmental Organization (NGO) accountability in a church and found that accountability of the church is different from nonreligious NGO accountability. Research on zakat management, as also one of the NGOs (Wahid et al., 2009, Wahid and Kader, 2010, Hadi and Yana 2011, and Huda and Sawarjuwono 2014) are included in the criteria for the issue of accountability.

Several studies of accountability on non-business organizations have tried to understand the religious practices of accounting and accountability. Basically, conventional management employs limited use of horizontal accountability instrument (stakeholders and nature), while the vertical accountability (God), which became the major premise (Triyuwono 2006,2012 ) in the accountability is still not fully used. In this study, the financial statements is limited as accountability media. Financial statements in the media is actually a physical form that connect people (agent, organization) with the principal (Triyuwono and Roekhudin 2000). This means that the agent and the principal relationship is not limited to the physical relationship, but also moral and spiritual relationship.

It must be understood that human beings are active and responsible (Triyuwono 2012). That is, on one hand man is free to be creative, but on the other hand, he/she is limited by 
his/her responsibility, which is always subject to the ethical values of sharia. The sharia ethical values are reflected in Islamic research methodology. In Islamic tradition, it is understood that the reality of the human family life is actually not limited to material reality, but also includes a higher reality, that is the reality of psychic, spiritual, nature of God, and God himself as absolute reality and the highest (Bakar 1994).

In the context of the mandate (amanah) metaphor (Triyuwono 2006 and 2012) philosophically, accountability is a mandate (amanah). A mandate (amanah) is something entrusted to others to be used appropriately in accordance with the wishes that have been instructed. It means that the party that gets the mandate does not have the right of possession (ownership) to what is mandated. However, it has an obligation to maintain the trust of the mandate giver and use it in accordance with the mandate intended by the giver. Triyuwono (2012) explicates that there are three important parts that must be considered in the metaphor of the mandate, i.e the mandate giver, recipient of the mandate, and the mandate it self. Grantor trust, in this case, is Allah, God the Creator of the Universe, the God who creates humans as Khalifatullah fil-Ardh (His representative on earth), as related in the Qur'an, which means "Remember when thy Lord said to the angel: Behold, I will make a vicegerent on earth." (QS. Al-Baqarah [2]: 30). In another letter Allah says: He was the one who made you caliphs in the earth (QS. Al-Fatir [35]: 39).

Being a caliph as stated, gives an understanding that a person who has been appointed as Caliph, is demanded to perform the tasks entrusted to him and run it according to what is desired by God. This study aims to find the values of Islam which can be used to develop the concept of accountability based on values of justice.

\section{METHODS OF RESEARCH}

In the history of the development of science, Islamic world has developed three types of epistemology in constructing knowledge. The three epistemology according to Abid alJabiry are epistemology Bayani, Burhani, and Irfani. (Abdullah 2007: 11-24). This epistemology has been successfully delivering exceptional achievements in knowledge of the Islamic world. It's only until recently that they have been abandoned as the Western technology flourished.

Epistemology bayani, is a method of thinking is based on the text (nass) of revelation. Sacred texts according to this epistemology is deemed to have full authority to give direction and meaning to the truth. Intellect is not given the freedom to determine the meaning and intent of the text, but he had to rely on the original text (Sumarna 2005).

Epistemology burhani, a source of knowledge that is rooted in reality or al-waqi', both the reality of natural, social, humanity, and religion. Sciences are compiled and systematized through the premises of logic or al-mantiq, and not through text or Salaf authority nor by the authority of intuition (Arif 2008). Thus, the underlying principle of Burhani epistemology is rationality, causality, and the essentiality of the main methods developed through deduction and induction. This epistemological approach model is based on the ability or sense ratio which is done through the arguments of logic, sequential meaning logic as its main epistemology (Sumarna 2005; Arif, 2008; and Alimuddin 2011).

Irfani epistemology constitutes a source of knowledge which is based on intuition rather than on the text and logic. A source of knowledge in the tradition of Irfani thinking is a direct experience on religious spiritual reality (Sumarna 2005).

According to Triyuwono (2006), this intuition process will enhance spiritual energy that can be used to obtain information directly from the All-Knowing, because the spiritual energy is connected with the Creator. Further more Triyuwono provides alternative instructions on how to obtain knowledge through intuition, by doing mental exercises. Basically, the inner exercise includes dhikr, prayer tahajjud will help a person to relax without any interference, then he/she can plead to the All-Knowing, and end the routine with praise to Allah (Triyuwono 2006).

Based on the explanation above, the epistemology that is used in this discussion is the epistemology of Islam, where the revelation (Qur'an and Sunnah) is placed at the sole and 
absolute truth and not inviolable. Therefore, this revelation has come down a few centuries ago, it is necessary to interpretation, both textually and contextually to be more operational.

In accordance with the qualitative research design developed Hamidi $(2010,54)$, there are eight stages of research work that are arranged with a more detailed explanation as follows:

Informant and Site Research. This research siteis in the Indigenous Region Ammatoa, which is located in South Sulawesi Province Bulukumba. The informants in this study are:

- Puang Hatong, Chairman of Zakat Management Organization village of Tana Toa, daily activities are farmers chocolate and clove.

- Puang Masong, Imam village of Tana Toa concurrently Imam Hamlet Balagana and Imam Hamlet Buttu. His daily activities as clove pickers.

- Jumarlin, traditional leaders/religious with daily activities as a civil servant at the Department of Forestry Bulukumba.

Approaches and Perspectives Research. This study used a qualitative approach with the typical presentation of the data in narrative form, in-depth or detailed stories of the informants based on interviews and observation (Hamidi 2010, 55). The researchers explored in-depth information related to the informants understanding of the concept of accountability both at normative and practical level.

Data collection technique. Data were collected through interview, observation (observation) and documentation of the research subjects. Items interview question are free and open. By its very nature tend to be flexible and follow the rhythm of the discussions that occurred between researcher and informant.

The second technique is the observation of the informant's behavior includes verbal and non-verbal actions at the time of the interview or other informal activities. Final data collection techniques was through documentation. This data collection techniques researchers use adapted to the conditions of the study sites.

Data Collection Strategy. The interview process largely took place in an informal situation, in a warm atmosphere but without leaving the element of seriousness. Conditions and situations as such are very important to be created to create rapport so that they are willing to be open, to participate and be happy to provide data or information that is needed by researchers (Hamidi, 2010, 156).

Data Analysis. Data obtained from the informant used as material to assess the understanding and application of the concept of accountability in the viewpoint of reality. So far the preparation of a concept, rules, norms and laws largely based on the reality that is happening in the field. The process of refining the data analysis through the stages of empirical material in the form of field notes are still roughly into research note. This stage is known as a process of exclusion-inclusion (Hamidi, 2010, 157). With this process, the simplification of data that contains the original statement of the informant has been transformed into several units and focused detailed information.

Data Validity examination techniques. There are several techniques examination of the validity of data that can be used, but this study focuses more on the triangulation method. According to Hamidi $(2010,68)$, the method triangulation technique emphasizes the need to test the results of interviews with the results of observation and documentation of data collected so that the level of validity of the collected data will be more accurate.

\section{RESULTS AND DISCUSSION}

Among the values of basic human justice brought by Islam and serve as the pillars of personal life, household, and community is justice (Qaradawi 2013: 201). In the Qur'an, justice is among human beings' heavenly goal, as Allah says:

"Indeed, We have sent Our Messengers with bringing tangible evidence and We have sent down with them the Bible and the balance (of justice) to enable people to carry out justice..." (QS. Al Hadid: 25).

The above verse emphasizes the value of justice through books of justice that are sent through God's apostles. 
Rawls (1999: 3) argues that, justice is an essential virtue in an organization. Everyone has the honor which is based on justice. Ibn Taymiyyah said, that "God uphold fair though pagan country, but does not enforce unjust country though a believer," and that "the world can survive with justice and wisdom, but not with injustice and Islam" (Chapra 1992: 230).

Ibn Taymiyya argued, that the justice system is everything. If world affairs are upheld by the justice, they would remain erected, even though the doer did not have a part in the afterlife. However, if they are not enforced with fairness, these affairs would not erect, although the doer has faith and would be rewarded in the after life (Islahi 1997).

Justice is an important foundation in Islamic economics. Justice has been emphasized in the Qur'an as the primary mission of the prophets sent by God, including the enforcement of economic justice and the elimination of the income gap. Allah revealed Islam as a system of life for all mankind, stressing the importance of justice in every sector, whether economic, political or social. Commitment of the Qur'an about justice is very clear. This is evident from the mention of the word justice in the Qur'anthat reached more than a thousand times (Suryani 2014). Justice is on the third place of the most mentioned words in the Quran after the words God and 'IIm (science).

In understanding economic justice, according to Hartropp (2010) there are three different ways to understand, namely the right, needs, and the reward. This understanding has similar meaning to a certain extent with each other, but all three were significantly different from each other and may be said to have conflict with each other.

In the view of Islam, the values of justice implies placing or distributing things according to the context (Shihab 2006). Fairness in the organizationoccurs where all stakeholders feel that there is a fair treatment between them. It is said to be unfair if there is a group of people who get special treatment compared with the other groups.

Thus economic justice in Islam includesjustice to oneself, justice to humanity, and justice to the environment. Economic justice to one self implies that everyone is trying to be able to meet their basic needs. This basic need comprises carrying out activities in the world and implementing the pillars of Islam (zakat and hajj). Economic justice to mankind is also essential through the provision of opportunity for individuals to meet their basic needs. The economy to environmental justice requires that every human being should protect, preserve, and maintain the environment which will result in sustainable development for the coming generation.

Justice values in Accountability. Man was created by God to care for this earth in order to achieve prosperity and happiness with should not take actions other than to justice. According to Alimuddin (2011), justice is one of the universal values upheld and to be the desire and hope of mankind whenever and wherever they are.

Caliph Umar bin Abdul Aziz has said that:

"It is the leader/authorities who must first be fair, then the people. If this is true, then justice is a shared responsibility. Long live a ruler sinned by doing a tyranny, the people also sin if they do not want to control and monitor. In fact, according to the Caliph Umar bin Abdul Aziz, the people who do not want to do itis entitled sanctioned punishment, especially if they do not deny immorality or injustice committed by the authorities" (Ahal 2002: 100).

The words of Umar bin Abdul Aziz can be interpreted that the demands for justice do not only apply for the ruler or leader, but also required for everyone.

Human is derived as khalifatullah fil ard (representative of God on earth) to carry out a mandate that must be done in accordance with the wishes of Allah (grantor trust) see Triyuwono (2006) . Humans are predicated as caliph in the earth are required to carry out a specific mandate (amanah) to do with a sense of responsibility.

There are three important parts that must be considered in the value of equity in accountability, namely: fairness transferring the mandate (amanah), justice in the conduct of amanah, and accounting for the value of justice in amanah.

Fairness in Transferring Amanah. Qutb (1994) argues that Islam gives freedom in the form of common humanity in its deepest meaning. However, Islam does not also allow freedom in chaos; faceted society has its own terms, humanity has its terms, and the high religious purpose also has certain values as well. Therefore, Islam establishes the principles 
of good-bad in humans in accepting freedom in this case accepting the mandate. Further, it also establishes rules for humans such that they include individual responsibility and community.

Islam does not forbid his people to be leaders (receiver amanah), even giving the widest possible opportunity to carry out a task (amanah) as a form of devotion. But Islam also does not want his people to be greedy, to provide an opportunity for individuals who have the ability to carry out the mandate (amanah).

Related to the above, Puang Hatong tells his appointment as a business leader in the village of Tana Toa Zakat Indigenous Regions Ammatoa:

In 1987, I was appointed by Imam of Desa Tana Toa to be the leader [imam] of Dusun Balagana... may be I was the leader for around 5 years. After that, I replace the Imam of Desa Tana Toa. I accepted this position after asking the consideration from the Ammatoa. Two years ago [2011]. I was asked to be replaced since there are already people who can replace me, and I have been doing this, collecting zakat in Desa Tana Toa for a long time. But the chief of the village said "hold on to it, because there still no one to be trusted". I have proposed BAZCAM [an organization that collects zakat] to do it, but the chief gave the same answer. So, Sir... until now I still take care of zakat (Interview dated June 2013).

Of the various explanations of the above, the meaning of which can be obtained from the value of justice in transferring the amanah according bayani method is that the position does not need to be asked. However, the amanah will be given if we are deemed able to take on the position or amanah .

By employing Burhani, it can be interpreted that human must equip himself with the knowledge that enables him to be capable and hard working. Without the hard work, he will not necessarily be a trustworthy leader.

Through Irfani it can be evaluated that the value of fairness in transferring the amanah is interpreted as getting a blessing and enjoyment. Any high position, if it is not blessed, it was short-lived. On the contrary, if it is an endowed position, it will be long-lived. Positions in jobs can be seen as dirt attached to our bodies that any time can be removed.

Justice in the Conduct of Amanah. Qutb (1994) argues that Islam guarantees between the individual and society, and between community members must walkin reciprocity and regulates the rights of each party. The guarantees given by Islam is really reached the level of unification between the two interests, and the boundaries of rewards and sanctions for anyone between the parties that are more active in mutual cooperation in various aspects of life, both material and that was immaterial.

Every individual, first became party guarantees to perform the work, each carried out with the best. Try your best at work is also a worship to God, for the work in a particular field that is owned by the community and ultimately benefit was restored to society. Described in the Qur'an Surah at-Tawbah:"And say: 'Work ye, then Allah and His messenger and the believers will soon see your work ..." (QS. At-Tawbah [9]: 105)

Each individual is also the person who ensures the interests of society as if they were here the guards were given the power to maintain it. Life is like sharing a boat in the middle of the ocean, and every passenger is responsible for safety, and there is no right for anyone to sink the ship on behalf of individual freedom (Qutb 1994). In a hadith narrated by Bukhari and At-Timidzi, with redaction of Bukhari; it is stated that:

"The likeness of an individual who tried to maintain the continuity of the Shari'ah of God is like the people who are on the ship; there while among those at the bottom and the other at the top. People who are at the bottom of the ship when fetching water, they will go through the people who live on them. So they then said: 'If we are holes in this ship (to draw water), we we will no longer disturb the people above us that! ". But if they were allowed to act like that, then everything will experience a disaster. But if they help one another, they must be saved".

The hadith gives a very clear picture about the necessity of tolerance and commonality of interests, with the exclusion of individuals who are not thought to think about the influence of the thinking of practical action. 
Of the various explanations of the above, the meaning of which can be obtained from the value of justice in carrying out the mandate (amanah) according bayani method is that the position (amanah) given by the giver of the mandate (amanah) should be implemented in accordance with the rules that have been set by the mandate giver. Through Burhani, it can be interpreted that if we carry out the mandate well, then Allah will bring down His blessings to us. Through Irfani method, it can be said that by carrying out the mandate (amanah) properly, we will get His blessings both in this world and in the Hereafter.

Accounting for the value of Justice in Amanah. Every human being is required to eliminate all forms of evil and injustice wherever he sees it. As described in the hadith narrated by Muslim , Abu Daut, At- Tirmidhi and An- Nasa'i :

"Whoever among you can see evil, then he should change it by hand (power), and if he can not do so, he should use his words, and if he is not able to do so, he should keep silent and this is the least of weak faith" (Qutb 1994: 90 )

Based on the hadith can be interpreted that each person is responsible for all forms of bad deed in society, even if in this case it alone without any friend. In a society that is a unity, if evil deed is found, it becomes an obligation for everyone to protect this community. Qutb (1994) explains that the whole community will be affected by the threat of sanctions and the punishment, both globally and in the hereafter, if all members of the community keep silent against any form of evil actions that occur on some of its members.

Each community is responsible for ensuring each of its members maintain the amanah. Described in the Qur'an Surah al-Isra':

"And if we want to destroy a country, then we ordered the people living in luxury in the country (in order to obey Allah) but they do iniquity in the land, then it is appropriate that the provisions applicable to him we, then we destroy that country"(Qur'an, Al-Isra' [17]: 16)

It is also described in the Tafsir Ibn Katsir that states that even among the many people who do not commit sin, if they keep silent against any form of wickedness that is all around them, then it is only fair God shatters them. It is also emphasized in the Qur'an Surah alAnfal "And fear of the torment that is not specifically override dzalim people among you..." (Qur'an, Al-Anfal [8]: 25). God's torment of this kind does not mean dzalim, because the community it self has committed bad deed, they have seen it but do not try to change it. This is a chaotic community and live towards their doom. Thus the destruction as God promised is a natural and common result.

In its mission to account for, people are required to be fair, as it has been described in this study. It is not only leaders who demanded justice, but members of the public too. Such is explicated by Puang Masong in the following:

During my appointment as Imam, seven days before Eid', I walked into people's homes to to tell them that it's time to pay zakka. Usually people paid directly but sometimes later. Once there was a zakka payer who was late to pay. So I tell him to reduce the payment. There are seven people in one house, but then he only paid for six people. He says "my wife just gave birth indeed, but only six people can I pay for. It's the least I owe you". Well ...I was forced to accept only the payment but I noted six people as the same report (while showing a recording sheet zakat) (Interview dated August 2, 2013).

Of the various explanations of the above, the meaning of which can be obtained from the value of justice in trust according bayani is that every human being should be held accountable in any way for amanah that has been given by the giver of the amanah. He is a leader and as well as a part of general society. The meaning of justice in trust according to Burhani is that any amanah given by God must be accounted for to avoid being penalized in the world or in the hereafter. Mean while, according to Irfani, the fairest accountability to the amanah is a form of servitude to Allah SWT.

\section{REFERENCES}

1. Abdul - Baqi , M.F. (2010). Sahih Bukhari Hadith Muslim set. Jakarta: Publisher Insan Kamil 
2. Alimuddin. (2011). Konsep Harga Jual Mashlahah Berbasis Nilai-Nilai Islam. Unpublished Doctoral Dissertation. Graduate School of Economics and Business. University of Brawijaya.

3. Al - Misri , M. (2008). Hiduplah Bersama Orang-Orang Jujur, Langkah Mudah Menikmati Hidup Penuh Berkah. Pustaka Arafah. Solo.

4. Bakar, O. (1994). Tauhid dan Sains: Esai-esai tentang Sejarah dan Filsafat Sains Islam (Tauhid and Science: Essays on the History and Philosophy of Islamic Science). Pustaka Hidayah. Jakarta.

5. Fikri, A., M. Sudarma, E.G. Sukoharsono, and B. Purnomosidi. (2010). Studi Fenomenologi Akuntabilitas Non Government Organization. Jurnal Akuntansi Multiparadigma. Vol. 1, No. 3, December 2010. pp. 409-420.

6. Fikri, A., and Z. Isnaini. (2013). Akuntabilitas Non Government Organization. Jurnal Ilmiah Akuntansi dan Humanika. Vol. 2, No. 2. June 2013, pp. 705-714.

7. Hadi, D. A. and Y.A. Anna. (2011). Hubungan Orientasi Pengurus LAZ terhadap Nilai Sosial Ekonomi: Pemanfaatan Zakat Dengan Kebijakan Pimpinan, Jurnal Ekonomi dan Keuangan Islam. Volume I,pp 39-60

8. Huda, N. and T. Sawarjuwono. (2014). Akuntabilitas Pengelolaan Zakat melalui Pendekatan Modifikasi Action Research, Jurnal Akuntansi Multiparadigma. Vol. 4, No. 3, December 2014, pp 376-388.

9. Salle, I. (2015). Akuntabilitas Manuntungi: Memaknai Nilai Kalambusang Pada Lembaga Amil Zakat Kawasan Adat Ammatoa. Jurnal Akuntansi Multiparadigma. Vol. 6, No. 1, April 2015, pp 28-37.

10. Lehman, G.(2004). Accounting, Accountability And religion: Charles Taylor's Catholic Modernity And The Malaise of A Dsenchanted World, Accepted for Presentation at the Fourth Asia the Pacific Interdisciplinary Research in Accounting Conference 4 to 6 July 2004 in Singapore.

11. Randa, F, I. Triyuwono, U. Ludigdo, and E.G. Sukoharsono. (2011). Studi Etnografi Akuntansi Spiritual pada Organisasi Gereja Katolik yang Terinkulturasi Budaya Lokal. Jurnal Akuntansi Multiparadigma. Vol. 2.No.1, April 2011, pp 35-51.

12. Sadjarto, A. (2000). Akuntabilitas dan Pengukuran Kinerja Pemerintahan, Jurnal Akuntansi dan Keuangan, Vol.2, No.2, pp 138-150.

13. Simanjuntak, A. D. and Y. Januarsi. (2011). Akuntabilitas dan Pengelolaan Keuangan di Masjid, Accounting National Symposium XIV. Aceh

14. Triyuwono, I. and Roekhudin. (2000). Konsistensi Praktik Sistem Pengendalian Intern dan Akuntabilitas Pada Lazis (Studi kasus di Lazis X Jakarta). Jurnal Penelitian Akuntansi Indonesia.Vol.3 No. 2.

15. Triyuwono, I. (2006). Akuntansi Syariah, Persfektif, Methodologi dan Teori. PT. Raja Grafindo Persada, Jakarta.

16. Triyuwono, I.(2012). Perspektif, Metodologi dan teori Akuntansi Syari'ah. Edisi Kedua. PT. Raja Grafindo Persada. Jakarta.

17. Uzaifah. (2007). Studi Deskriptif Prilaku Dosen Perguruan Tinggi Islam DIY dalam Membayar Zakat. La Riba Jurnal Ekonomi Islam. Vol. 1, No. 1, p. 127-143.

18. Wahid, H., S. Ahmad, and R.A. Kader. (2009). Penagihan Zakat oleh Institusi Zakat kepada Lapan Asnaf: Kajian Malaysia. Seminar on "Ekonomi Islam Peringkat Kebangsaan". Malaysia.

19. Wahid, H. and R.A. Kader. (2010). Localization of Malaysian Zakat Distribution: Perceptions of AMIL and Zakat Recipients, Seventh International Conference - The Tawhidi Epistemology: Zakat and Waqaf Economy, Bangi. 